\title{
PARADIGMA SISTEM KEUANGAN ISLAM DALAM MENGHADAPI KRISIS
}

\author{
Mohammad Yahya Mamun Mutho* \\ Ekonomi Syariah/UIN Maulana Malik Ibrahim Malang \\ Moch Anshori \\ Ekonomi Syariah/UIN Maulana Malik Ibrahim Malang
}

\begin{abstract}
The state of the financial crisis in the economy is a condition that continues to occur at a certain time. Finding economic systems and mechanisms that are able to withstand this crisis is an important task that must continue to be carried out. By using induction and literature study to analyze the results of previous empirical research, a framework is created to explain how Islamic finance will respond to future crises. This article finds that the conventional financial system is the main cause of the crisis, especially in behavioral, political and economic aspects.
\end{abstract}

Keywords: System, finance, crisis.

Paper type: Research paper

*Corresponding author: Yahyamutho150593@gmail.com

Received: February 02, 2021; Accepted: November 13, 2021; Available online: December, 06, 2021

Cite this document:

Mutho, M. Y., \& Anshori, M. (2021). Paradigma Sistem Keuangan Islam dalam Menghadapi Krisis. Jurnal Masharif Al-Syariah: Jurnal Ekonomi dan Perbankan Syariah, 6(3), 670-690. doi:http://dx.doi.org/10.30651/jms.v6i3.7566

Copyright (C) 2021, Jurnal Masharif Al-Syariah: Jurnal Ekonomi dan Perbankan Syariah http://journal.um-surabaya.ac.id/index.php/Mas/index

This article is licensed under a Creative Commons Attribution-NonCommercial $\underline{4.0 \text { International License. }}$ 


\begin{abstract}
Abstrak
Keadaan krisis keuangan dalam perekonomian merupakan keadaan yang terus menerus terjadi pada waktu tertentu. Menemukan sistem dan mekanisme ekonomi yang mampu menahan krisis ini merupakan tugas penting yang harus terus dilakukan. Dengan menggunakan induksi dan studi pustaka untuk menganalisis hasil penelitian empiris sebelumnya, maka dibuat kerangka kerja untuk menjelaskan bagaimana keuangan Islam akan merespon krisis di masa depan. Artikel ini menemukan bahwa sistem keuangan konvensional merupakan penyebab utama terjadinya krisis, terutama pada aspek perilaku, politik dan ekonomi.
\end{abstract}

Kata kunci: Sistem, keuangan, krisis.

\title{
PENDAHULUAN
}

Keadaan krisis keuangan dalam perekonomian merupakan keadaan yang terus menerus terjadi pada waktu tertentu. Menemukan sistem dan mekanisme ekonomi yang mampu menahan krisis ini merupakan tugas penting yang harus terus dilakukan. Prediksi resesi dan krisis pada tahun 2020 memang banyak disebut-sebut. The Guardian menyatakan bahwa saat ini, lemahnya pertumbuhan baik di negara berkembang maupun negara maju mengindikasikan kemungkinan terjadinya resesi ekonomi dan krisis keuangan di tahun-tahun mendatang, hal ini merupakan ancaman nyata bagi perekonomian dunia saat ini. Lebih lanjut Larry Summers (2019) juga menyatakan bahwa kemungkinan Amerika Serikat sebagai pusat pasar keuangan dunia akan mengalami resesi ekonomi pada tahun 2020 hampir 50\%. Nouriel Roubini (2018), Ekonom yang memprediksi dengan tepat krisis keuangan global tahun 2008, juga memprediksikan bahwa krisis keuangan dan resesi global akan terjadi pada tahun 2020, kejadian ini memperkuat argumen bahwa kondisi keuangan global kembali berpeluang besar untuk jatuh. 
Alrifai (2015) menjelaskan bahwa krisis keuangan yang akan datang akan terus terjadi karena memang sistem keuangan yang ada mempunyai sifat yang memicu terjadinya krisis. Makalah ini mencoba membangun kerangka konseptual untuk krisis keuangan dan solusinya dari sudut pandang penyebab utama krisis.

Secara umum pengakuan bahwa sistem keuangan syariah lebih stabil di saat krisis keuangan telah banyak disebutkan, bahkan Lembaga Keuangan Bank Islam sebagai bagian dari sistem Keuangan cenderung tidak terpengaruh oleh krisis keuangan (Derbali, 2015), serta Lembaga Keuangan Non Bank seperti asuransi syariah, tidak terpengaruh oleh krisis keuangan global dengan bukti bahwa permintaan asuransi syariah cenderung tidak berubah pada saat krisis keuangan (Akhter et al., 2017). Di pasar modal, krisis keuangan global berdampak negatif terhadap return aset saham dan obligasi, namun pendapatan saham dan obligasi syariah memiliki pengaruh yang lebih kecil dibandingkan asset saham dan obligasi konvensional (Akhtar \& Jahromi, 2017). Ketika keyakinan tentang stabilitas keuangan syariah dalam menghadapi krisis terus digaungkan, ternyata beberapa penelitian menunjukkan bahwa sektor keuangan syariah khususnya perbankan syariah belum mampu menghadapi krisis dengan cukup baik, baik dalam dari segi keuntungan yang cenderung lebih buruk dari konvensional (Alexakis et al., 2019)) dan penderitaan serta guncangan yang diterima bank syariah cenderung lebih besar ketika menghadapi krisis (Alqahtani \& Mayes, 2018). Dari sini terlihat bahwa masih terdapat gap antara penelitian empiris yang satu dengan yang lainnya.

Makalah ini diawali dengan menjelaskan konsep Krisis Keuangan dari beberapa teori, kemudian menjelaskan penyebabnya dari sudut pandang penelitian sebelumnya, jenis dan perkembangan teori tersebut serta sudut pandang yang dibangun oleh para peneliti tersebut, maka makalah ini juga akan menjelaskan perbedaan yang muncul dari penelitian penelitian empiris yang membandingkan antara sistem keuangan Islam dan konvensional dan menggambarkan hasilnya. Pada 
bagian selanjutnya penulis mencoba menjelaskan teori paradigma sistem keuangan syariah dalam menghadapi krisis keuangan global dan instrumen apa saja yang mendasari stabilitas keuangan syariah. Dan pada bagian akhir makalah ini penulis mencoba membangun model paradigma keuangan syariah dalam menghadapi krisis berdasarkan sebab-sebab dan memberikan solusi berdasarkan masing-masing penyebab yang menjadi pemicu krisis.

\section{KAJIAN PUSTAKA}

\section{Teori Krisis Keuangan (Financial Crisis Theory)}

Dalam perkembangan teori krisis keuangan terdapat lima teori yaitu model generasi pertama, model generasi kedua, model generasi ketiga, teori siklus bisnis Austria dan teori Heyman Minsky (Ascarya, 2017). Aryani (2015) menjelaskan bahwa krisis keuangan pada dasarnya merupakan fenomena (fenomena) resesi atau keruntuhan di semua sektor ekonomi yang mempengaruhi semua sektor lainnya.

Teori krisis keuangan pada awalnya merupakan respon terhadap krisis mata uang di Inggris pada tahun 1825 dan 1837 (Ascarya, 2017). Di Amerika Serikat, situasi ini biasanya terjadi dalam interval waktu yang relatif singkat, seperti krisis utang Amerika Latin (1982), Black Monday (1987), dan krisis simpan pinjam Amerika Serikat (1989).

Krisis ekonomi yang jika dikaitkan dengan konsep ekonomi Islam dalam Alquran merupakan bagian dari hasil korupsi manusia (frontal) (QS Ar-Ruum (30): 41), terutama dalam konteks ekonomi yang akan merusak sistem perekonomian. Stabilitas. Pelanggaran utama adalah transaksi Labawi (QS Al-Baqarah (2): 275-279), Maysir (perjudian) (QS Al-Maidah 5: 90), Gharar yang mengakibatkan konsumsi bentuk harta milik orang lain dengan cara yang salah (palsu). (Surat Al-Baqarah (2): 188; QS An-Nisa (4): 29).

Respon terhadap krisis keuangan dan pengembangan model dimulai dari generasi pertama (generasi pertama) yang bersumber dari hasil model yang dikembangkan oleh Krugman (1979) dan Flood and Garber (1984). Krugman membentuk model krisis berdasarkan neraca 
pembayaran, model dipengaruhi oleh nilai tukar spekulatif, serangan spekulatif juga menyerang pemerintah yang pada akhirnya mempengaruhi pengambilan keputusan dan penerbitan instrumen keuangan. Kemudian Flood \& Garber (1984) memperkuat teori ini dengan menekankan bahwa interferensi yang tidak terduga selama penerapan nilai tukar tetap (sistem nilai tukar tetap) dapat sangat mempengaruhi nilai tukar mata uang. Teori generasi pertama diperpanjang oleh Drazen \& Helpman (1987), Calvo (1987) dan Wijnbergen (1991) memandang krisis dari perspektif batasan anggaran pemerintah rentang waktu dan optimalisasi konsumen. Krisis yang terjadi dan coba diteliti pada generasi pertama menghasilkan beberapa teori dasar tentang krisis keuangan. Menurut Ascarya (Ascarya, 2017), dari perspektif Islam, dari perspektif teori generasi pertama, permasalahan utama krisis bersumber dari masalah mendasar sistem moneter, antara lain sistem moneter, sistem suku bunga, dan uang kertas. Kelebihan pasokan, defisit fiskal yang berlebihan, spekulasi dan ekspektasi.

Teori generasi kedua yang dikemukakan oleh Obstfeld \& Rogoff (1986) berupaya untuk menutupi kelemahan teori generasi pertama dengan menitikberatkan pada aspek makroekonomi Model ini memiliki model yang lebih mikroskopis dan sangat erat kaitannya dengan pengawasan pemerintah terhadap lembaga keuangan untuk mempertahankan kreditor. Koordinasi dan keseimbangan. Pemeliharaan dan penyesuaian koordinasi bank sentral merupakan salah satu pengembangan dari model ini. Munculnya sistem cadangan fraksional dan berkembangnya respon terhadap permasalahan perbankan seperti kredit macet, pengaturan suku bunga bank ditetapkan oleh teori generasi kedua. Dari perspektif ekonomi Islam, permasalahan generasi kedua terkait dengan lembaga keuangan, seperti spekulasi, ekspektasi, bagian dari sistem perbankan cadangan, sistem leverage, kredit macet, lembaga keuangan bermasalah, dan sistem suku bunga. (Ascarya, 2017)

Ascarya (2017) menjelaskan bahwa generasi ketiga didasarkan pada kekurangan model generasi kedua, namun jika mempelajari generasi 
ketiga lebih dalam untuk mencoba mencari keterkaitan antara generasi pertama dan kedua, maka model generasi pertama Ini akan lebih fokus pada aspek makro ekonomi, terutama model krisis. Berdasarkan neraca pembayaran, generasi kedua berfokus pada model krisis lembaga keuangan, khususnya industri perbankan, namun teori krisis generasi ketiga menunjukkan bahwa model generasi pertama dan kedua saling terkait, karena sebagian besar krisis mata uang terkait dengan keuangan. Krisis departemen terjadi pada saat bersamaan, Model generasi ketiga, seperti yang ditulis oleh Diaz-Alejandro (1985) dan Kaminsky \& Reinhart (1999), menyimpulkan bahwa fenomena krisis disebabkan oleh hal-hal yang kompleks dari mikro hingga makro.

Teori perkembangan selanjutnya tentang krisis keuangan adalah teori siklus bisnis Austria atau teori $\mathrm{ABCT}$, asumsi dasarnya seperti yang dikemukakan dalam Zelmanovitz (2011) bahwa mata uang tidak netral, dan fluktuasi nilainya adalah apa yang terjadi dan terjadi. Dalam ekonomi riil.

Para ekonom biasanya menyebut siklus ini sebagai siklus kredit yang terdiri dari empat tahapan yaitu ekspansi, krisis, resesi dan pemulihan, tahapan tersebut terlihat dari karakteristik kegiatan perkreditan. Tahap krisis dimulai dengan koreksi ekspansi kredit, yaitu ketika suku bunga turun dan terjadi penciptaan kredit, preferensi konsumsi kreditor tidak diperhatikan (Isaic et al., 2019), ketika tingkat konsumsi meningkat tetapi kemampuan membayar menurun hingga terjadi kredit macet dan gagal membayar. Dalam hal jumlah uang beredar, jumlah uang beredar meningkat untuk tujuan konsumsi tanpa preferensi untuk investasi, yang menyebabkan jatuhnya pasar modal. (Ascarya, 2017; Isaic dkk., 2019)

Teori lain yang berkaitan dengan krisis keuangan adalah hipotesis ketidakstabilan keuangan Hyman Minsky (1982, 1989, 1992). Asumsi dasarnya adalah bahwa ekonomi kapitalis tidak stabil. Teori ini sejalan dengan Alrifai (2015) Yang terakhir percaya bahwa ekonomi konvensional, terutama yang didasarkan pada hutang, tidak stabil dan melekat dalam sistem ekonomi saat ini. (Alrifai, 2015) 
Kata kunci untuk mekanisme yang menyebabkan ketidakstabilan ekonomi adalah akumulasi hutang, dan Minsky menekankan perilaku peminjam dan aktivitas pinjaman yang ada saat mengembangkan teorinya. Menurut dia, ada tiga jenis peminjam, yakni peminjam lindung nilai, peminjam spekulatif, dan peminjam ponzi. Jenis peminjam atau peminjam lindung nilai yang pertama adalah peminjam yang dapat mengembalikan hasil usahanya dan hutang arus kasnya berdasarkan hasil usaha dan hasil usahanya, sedangkan peminjam spekulatif tetap dapat mengembalikan semula. Pinjaman hutang untuk memenuhi kewajiban membayar hutang. Peminjam ponzi adalah kelompok yang paling rentan dan paling sulit untuk mengembalikan pinjaman awal karena mereka hanya mengandalkan apresiasi asetnya untuk melunasi hutangnya. (Ascarya, 2017).

Dalam beberapa penelitian selama dan setelah krisis keuangan 2008, banyak penjelasan yang diberikan tentang penyebab utama terjadinya krisis keuangan tersebut. Beberapa peneliti menyimpulkan bahwa penyebab krisis tersebut adalah perilaku, seperti spekulasi oleh pelaku ekonomi ( Trabelsi, 2011; Almoharby, 2011). ). Selain itu, perilaku yang diharapkan juga menjadi faktor penyebab terjadinya krisis (Siddiqi, 2009). Peningkatan kejahatan sosial juga menjadi bagian dari krisis keuangan (Mirakhor \& Krichene, 2009). Dari perspektif politik (politik), peran pemerintah dalam pengendalian harga juga dianggap sebagai penyebab terjadinya krisis keuangan (Khan \& Thaut, 2008; Rothbard, 2009). Dikatakan bahwa proteksionisme pemerintah juga turut mempengaruhi krisis dan menjadi penyebabnya, namun hal tersebut berkaitan dengan hal tersebut. Karena perbedaan pandangan tentang proteksionisme perdagangan itu sendiri, maka proteksi perdagangan terus berkembang (Trabelsi, 2011).

Selain aspek perilaku dan politik, aspek ekonomi (ekonomi) juga menjadi perhatian peneliti.Hal inilah yang menjadi penyebab terjadinya krisis. Dari aspek moneter, sistem uang kertas (fiat currency) menjadi salah satu penyebabnya (Trabelsi, 2011; Lietaer \& Dunne, 2013 ) Sistem 
Ribawi (bunga atau riba) merupakan faktor fundamental yang menyebabkan terjadinya krisis keuangan (Trabelsi, 2011; Othman et al., 2012; Lietaer \& Dunne, 2013). Dari perspektif fiskal, hutang pemerintah yang tinggi suatu negara (Othman et al., 2012) dan pengelolaan komoditas strategis yang buruk juga dapat memicu dan memicu krisis (Chapra, 2008; Rothbard, 2009).

\section{METODE PENELITIAN}

Penelitian ini merupakan penelitian kualitatif dengan pendekatan induktif (inductive reasoning) (Feeney \& Heit, 2007; Ketoviki \& Mantere, 2010; Bendassolli, 2013) melalui proses studi kepustakaan (Library research). Sumber data yang digunakan untuk membangun konseptual adalah data-data sekunder yang berasal dari hasil penelitian-penelitian terdahulu dalam bentuk tulisan (artikel) yang membahas tentang krisis keuangan dan melakukan analisa mendalam terhadap data-data tersebut untuk menghasilkan sebuah kesimpulan dan model.

Langkah-langkah induktif yang penulis gunakan dalam penelitian ini menggunakan pendekatan pemikiran penelitian khusus ke Umum (Feeney \& Heit, 2007) dengan urutan sebagaimana yang disebut oleh Bendassoli (2013) sebagai 'Generic Analytic cycle'. Pertama, Penulis melakukan kontak dengan material data dalam bentuk pembacaan umum (General reading) diikuti dengan pembacaan secara cermat (careful reading) terhadap setiap informasi yang dalam hal ini berasal dari penelitianpenelitian sebelumnya tentang krisis keuangan. Kedua, sebagai hasil dari langkah pertama penulis mencoba membentuk pola dengan melakukan penyimpulan secara deduktif dari setiap artikel dengan mengerucutkan kesimpulan umum menjadi kesimpulan khusus ke arah yang berkaitan dengan kesimpulan ke arah tema krisis keuangan, baik dari sisi penyebab maupun kesimpulan umum lainnya yang diperlukan untuk membangun kesimpulan. Ketiga, dari setiap hasil kesimpulan tersebut, penulis membangun konseptual paradigma stabilitas keuangan itu dengan pengkategorisasian penyebab krisis dan pengkonseptualisasian paradigma tentang stabilitas keuangan Islam tersebut di mana pada tahap 
ini penelitian bertujuan untuk mengekstrak materi menjadi lebih kecil sekaligus meningkatkan abstraksi dari sebuah konsep yang penulis sebut sebagai paradigma stabilitas keuangan Islam dalam menghadapi krisis.

Menurut Ketoviki dan Mantere (2010) strategi penalaran (reasoning) dengan pola yang penulis lakukan ini merupakan strategi dengan pendekatan idealisasi (idealization) di mana secara umum dan penelitian besarnya merupakan alur penelitian induktif, namun di dalamnya juga terdapat proses deduktif dari setiap bahan dan hasilnya dalam bentuk generalisasi konsep ataupun model yang dibangun.

\section{HASIL DAN PEMBAHASAN}

Krisis keuangan yang berulang hampir pernah dialami negaranegara di dunia, terutama negara-negara yang menjadi pusat sistem ekonomi dunia, seperti Amerika Serikat (Alrifai, 2015). Pada abad terakhir, krisis seperti ini kembali terjadi, dari Pada tahun 1929, pasar saham AS memicu Wall street crash and great depression yang dipicu oleh stock market crash, dan kemudian krisis minyak pada tahun 1973 ketika harga minyak meroket, Kemudian datanglah krisis hutang Amerika Latin pada tahun 1982, yang dipicu oleh gagal debt default, "Black Monday" pada 1987, simpan pinjam AS krisis pada tahun 1989, krisis tahun 1990-an telah menyebar ke belahan dunia lain, seperti Asia, dimulai Japanese asset bubble pada tahun 1990, krisis mata uang peso Meksiko tahun 1994, krisis keuangan Asia tahun 1997, krisis keuangan Rusia tahun 1998, kemudian Dot-com bubble pada tahun 2000 dan terakhir krisis keuangan global tahun 2008 yang dipicu oleh kredit macet perumahan yang berefek terhadap industri keuangan global (Alrifai, 2015). Dalam waktu kurang dari satu abad, rentetan krisis yang berulang menunjukkan bahwa sistem keuangan konvensional yang ada perlu dikritisi dan dicarikan solusinya. Dalam perkembangan aliran utama ilmu ekonomi Islam, terutama setelah tahun 1970-an, perkembangan ekonomi Islam sendiri mulai bersungguh-sungguh mencari sumber permasalahan ekonomi, dan mulai mengembangkan Islam melalui proses Islamisasi keilmuan di berbagai bidang termasuk ilmu ekonomi (Furqani, 2015) untuk 
mengatasi masalah ini. Menurut Furqani (2015), arah perkembangan ekonomi Islam ke depan adalah arah pembangunan. IImu ekonomi Islam harus dibangun dengan ide-ide yang khas, yang bersumber dari landasan pemikiran ekonomi Islam, yang berbeda dengan ilmu ekonomi kovensional yang berkembang sebagai sebuah solusi dan paradigma pengetahuan yang independen dan khas dalam memecahkan problem ekonomi.

Sebagai salah satu bentuk pengembangan keilmuan ekonomi Islam dan langkah memberikan kontribusi dalam pemecahan masalah ekonomi yang sedang berkembang, penelitian ini meyakini bahwa fenomena krisis ekonomi merupakan masalah yang berulang sehingga membutuhkan paradigma yang benar untuk mencapai solusi stabilitas keuangan. Ini didasarkan pada paradigma keuangan Islam.

\section{Empirical Evidence tentang Stabilitas Keuangan Islam}

Dalam beberapa dekade terakhir, perkembangan keuangan syariah telah mendorong para peneliti untuk mengkonfirmasi teori dan hasil penelitian sebelumnya. Pertanyaan telah diajukan tentang sejauh mana sistem keuangan Islam yang berkembang pesat dapat menahan krisis keuangan berkala. Beberapa peneliti telah memperkuat argumen secara empiris bahwa sistem keuangan Islam baik di pasar keuangan dan lembaga Intermediasi sangat baik dalam merespon krisis keuangan (Akhtar dan Jahromi, 2015; Derbali, 2015; Akhter et al. People, 2017; Ascarya, 2017). Akhtar \& Jahromi (2015) menunjukkan bahwa ketika pasar modal konvensional secara signifikan dipengaruhi oleh krisis keuangan, maka dampak pasar modal syariah yang dijelaskan oleh pendapatan saham dan obligasi syariah seringkali lebih kecil dibandingkan dengan pasar modal konvensional. Akhter et al. (2017) menemukan bahwa pada saat krisis, jumlah permintaan terhadap lembaga asuransi syariah tidak terpengaruh secara signifikan, bahkan aktifitas keuangan yang secara langsung berkaitan dengan volatilitas transaksi keuangan semisal saving rate disebutkan tidak memiliki hubungan dengan Asuransi Islam, yang lebih berpengaruh kepada Lembaga Islamic insurance adalah indikator substansial seperti pendidikan (education), 
Walaupun perbedaan lokasi penelitian dan objek penelitian juga akan memiliki hasil estimasi yang berbeda pula atas perbedaan karakteristik negara seperti Timur Tengah dan negara ASEAN, hal tersebut tidak mengubah hasil kesimpulan umum bahwa lembaga keuangan syariah lebih tangguh dalam menghadapi krisis keuangan (Akhter, 2017).

Temuan yang menarik adalah bahwa dalam industri perbankan, Derbali (2011) mengemukakan bahwa berdasarkan analisis data perbankan tujuh negara dari tahun 2006 hingga 2012 ditemukan bahwa bank syariah tidak terpengaruh oleh krisis keuangan tahun 2007, bahkan dalam ekspansi ekonomi. Dalam keadaan tersebut, sistem keuangan Islam juga dapat menjadi solusi untuk ilmu ekonomi konvensional, karena pada saat krisis datang, menurut hasil penelitian ini laba bank syariah terus meningkat (Derbali, 2011). Ascarya (2017) melakukan studi empiris yang lebih luas, ia mempelajari dan membandingkan model teori keuangan Seperti halnya keuangan syariah, kedua model ini telah mengembangkan Growth model (GM) maupun Inflation model (IM). Hal ini menunjukkan bahwa sistem keuangan Islam lebih baik daripada sistem keuangan tradisional. Dari sudut pandang hulu, GM dan IM merupakan sumber utama krisis terbesar. Alasannya adalah riba atau bunga. Sementara itu, Profit and Loss Sharing (PLS) yang disediakan oleh keuangan syariah merupakan cara untuk mengatasi ketidakstabilan sistem keuangan. Namun, studi empiris lainnya menemukan hasil yang berbeda. Alexakis et al. (2019) saat melakukan penelitian dengan dasar teori Produktifitas Malmquist (Malmquist Productivity theory) menemukan bahwa dari aspek Performa biaya, Bank Syariah lebih buruk daripada Bank Konvensional pada saat krisis, artinya secara biaya bank Islam tidak lebih efisien dari bank konvensional, dari sisi pendapatan (Revenue) ditemukan bahwa tidak ada perbedaan signifikan antara kedua jenis lembaga perbankan, bahkan dari sisi keuntungan (Profit) Bank Islam lebih buruk daripada Bank konvensional. Penelitian di atas sejalan dengan penelitian Alqahtani \& Mayes (2018) yang menunjukkan bahwa ketika krisis keuangan melanda dan berdampak pada perekonomian riil di akhir 
fase krisis, bank syariah lebih menderita daripada bank tradisional dan mengalami stabilitas keuangan. Sulit, hasil ini terutama muncul di bankbank syariah besar, dan Bank-bank kecil Islam terbukti mampu menghadapi situasi ini lebih baik, jadi kesimpulannya adalah bank syariah akan lebih stabil hanya untuk skala kecil dan akan kehilangan kemampuan untuk menjaga stabilitas dalam skala yang lebih besar (Alqahtani \& Mayes, 2018). Secara khusus, studi empiris ini tampaknya saling eksklusif kontradiktif, tetapi jika Anda menganalisis studi tersebut lebih dalam Memperkaya temuan penelitian keuangan Islam.

Perspektif yang berbeda membuat penelitian ini berbeda.Misalnya, Alqahtani \& Mayes (2018) menunjukkan bahwa ketika bank syariah melarang berbagai metode hal tersebut menjadi bagian dari kelemahan bank syariah dalam mengatasi masalah likuiditas dan menerapkan manajemen risiko dengan berbagai keterbatasan termasuk pada saat masuk di sisi lain, ketika pasar uang antar bank menggunakan alat bantu untuk aktivitas manajemen risiko seperti opsi, kontrak berjangka dan kontrak berjangka, maka adanya pembatasan tersebut akan meningkatkan risiko operasional bank syariah (Alqahtani \& Mayes (2018), selain itu, pada level kontraktual, ketika bank syariah memperluas skala kreditnya melalui kontrak hutang, bahkan jika Islam melarang lembaga keuangan untuk menjual obligasi sebagai salah satu kegiatan sekuritisasi untuk mengatasi risiko kredit, hal itu akan membuat bank syariah terkena risiko kredit. Asumsi dasar ini berbeda dengan asumsi dasar bahwa semakin sebuah lembaga yang mengikatkan diri kepada syariah terikat pada syariah, maka semakin tinggi tingkat kemashlahatannya, sebagaimana kaidah fiqih 'di mana ada hukum syariah maka ada kemashlahatan di dalamnya' dan asumsi ini ada pada penelitian lain semisal Derbali (2011) dan Ascarya (2017). Perbedaan paradigma dan cara pandang yang membentuk hipotesis ini juga menjadikan hasil penelitian sebagai salah satu penyebab perbedaan hasil aktivitas empiris.

Selain itu penggabungan model antara bank syariah dan bank konvensional menjadi satu model tanpa memperhatikan ukuran (size), 
scope dan pangsa pasar dalam penelitian Alexakis et al. (2019) dan hanya berfokus langsung pada pengukuran produktivitas tentu bisa saja menghasilkan bias penelitian dan perbandingannya bersifat tidak Apple to Apple sehingga tentu kemampuan bank syariah akan terlihat lebih buruk daripada bank konvensional. Dengan demikian, sistem dual bank sebagai sistem keuangan yang komprehensif merupakan solusi dari krisis keuangan yang ada. Bank syariah dan bank tradisional pada dasarnya memiliki karakteristik yang berbeda, dan mereka juga memiliki cara yang berbeda dalam menghadapi krisis. Dalam hal stabilitas, fleksibilitas dan keuntungan serta pertumbuhan modal saat krisis, bank syariah lebih baik dari bank konvensional. Tetapi berbicara tentang efisiensi, likuiditas dan manajemen asset, bank konvensional dengan skala, umur dan cakupan yang lebih besar akan lebih baik dari bank tradisional (Hamdi et al., 2019).

\section{Dasar Stabilitas Sistem Keuangan Islam dalam Menghadapi krisis}

Sistem keuangan Islam yang berkembang secara fundamental dan teknis mampu menjaga stabilitasnya dalam menghadapi krisis keuangan. Berdasarkan perkembangan teori krisis keuangan, Minsky (1978, 1989, 1992) mengembangkan teori kapitalis tentang ketidakstabilan keuangan, sedangkan Islam adalah landasan pembentukan sistem keuangan Islam memiliki asumsi tersendiri yaitu hakikat dan hakikat dari sistem keuangan Islam adalah sistem yang stabil (Alrifai, 2015; Ascarya, 2017), Ini karena Islam itu unik dan tidak bisa didefinisikan oleh sistem ekonomi lain seperti kapitalisme dan sosialisme (Askari \& Zahedi, 2017). Secara fundamental, kedua sistem keuangan tersebut akan berbeda dalam merespon kondisi krisis.

Stabilitas ekonomi biasanya dibakukan dengan indikator makroekonomi dalam perekonomian, seperti output produksi dan inflasi memang berbeda dengan stabilitas keuangan yang diidentikan dengan kondisi sistem keuangan dan ketahanan sistem tersebut dalam mengatasi goncangan (shock) baik dari dalam maupun luar sistem dan sejauh mana efek goncangan tersebut berpengaruh ke seluruh sistem yang terkait, 
namun kedua hal tersebut tidak bisa dipisahkan dan saling mempengaruhi (Maghrebi et al., 2016).

Sistem keuangan Islam sangat erat kaitannya dengan ekonomi riil (lqbal \& Mirakhor, 2011; Alrifai, 2015; Askari, dll, 2017). Selain itu, sistem keuangan Islam melarang hutang berbasis bunga (riba) dan mendorong sistem pembagian risiko, yang mendorong sistem tersebut untuk membentuk hubungan langsung antara sektor riil dan sektor keuangan. Alhasil, sistem keuangan Islam telah menghasilkan sistem yang menciptakan aspek "substansial" yang menghubungkan pembiayaan langsung dengan aset dasar, sehingga secara jelas melakukan kegiatan pembiayaan, memperjelas sektor fisik dan mampu bertahan dalam kondisi krisis keuangan yang parah. Beberapa ekonom percaya bahwa 2008 adalah tahunnya krisis keuangan yang disebabkan oleh pasar derivatif merupakan krisis keuangan paling serius dalam sejarah, jauh dari faktor ekonomi riil (Alrifai, 2015), yang juga membuktikan bahwa sektor keuangan syariah dapat merespon dengan baik (Akhtar dan Jahromi, 2015) Tahun; Derbali, 2015; Akhter et al., 2017; Ascarya, 2017; Hamdi et al., 2019).

Kontrol ketat penyimpangan perilaku dalam aktivitas keuangan Islam ini juga salah satu alasan mengapa keuangan Islam dapat menahan krisis. Hal-hal yang melanggar hukum Islam, seperti Riba, Maysir, Gharar, dan penekanan akhlak Islam dalam kegiatan konsumsi, produksi dan distribusi adalah salah satunya guna mengendalikan masalah perilaku yang menyebabkan krisis keuangan. Dalam aktivitas akad, Islam mengatur dengan sangat rinci setiap basis transaksi yang dilakukan (lqbal \& Mirakhor, 2011), dengan basis transaksi yang beragam semisal jual beli (Bay'), Sewamenyewa (ljarah) dan akad kebaikan (Tabarru') maka perilaku para perilaku transaksi akan terarah sesuai karakter dari basis akad yang dilakukan, selain itu aka nada transfer resiko antara satu akad dengan akad yang lain (Alrifai, 2015). Berbeda dengan sistem keuangan konvensional yang menjadikan hutang (Debt) sebagai basis seluruh transaksi sehingga mengarah kepada excessive debt yang menjadi salah 
satu pemicu krisis keuangan (Chapra, 2008; Alrifai, 2015). Jika dalam Ekonomi Konvensional dengan asas Laissez faire membebaskan para pelaku dan menyerahkan keseimbangan ekonomi termasuk pada pasar keuangan pada mekanisme pasar bebas sehingga tidak ada kontrol terhadap perilaku pasar, maka berbeda dengan Islam yang menempatkan peran pemerintah sebagai kontrol terhadap perilaku pasar namun tidak mencampuri mekanisme pasar (Karim, 2009) sehingga alasan teknis yang didorong oleh penyimpangan moral dan perilaku disebutkan oleh para peneliti sebagai salah satu akar masalah terjadinya krisis keuangan (Askari et al., 2017) dapat diminimalisir.

Oleh karena itu, secara umum Islam memiliki sifat yang stabil berdasarkan sistemnya yang terkait dengan sistem ekonomi riil untuk mengontrol perilaku yang dapat memicu perilakunya Krisis telah mendorong pemerintah untuk mengontrol perilaku abnormal para pelaku pasar.

\section{Paradigma Stabilitas Keuangan Islam dalam menghadapi Krisis}

Pada teori-teori awal, perkembangan krisis keuangan lebih difokuskan Membahas aspek makro dan mikro ekonomi dan peraturan pemerintah, Namun paska terjadinya krisis tahun 2007/2008 analisa penyebab krisis lebih banyak berfokus kepada hal-hal seperti buruknya aturan, konflik kepentingan pada perusahaan, sekuritisasi asset berbasis hutang, pergeseran atau perubahan resiko dari inovasi keuangan, tumbuh dan berkembangnya hutang publik maupun swasta dan aspek-aspek yang ditimbulkan oleh perilaku para pemain-pemain besar di pasar keuangan, Meski masih sangat jarang diskusikan lebih lanjut tentang aspek dasar mengapa hal di atas terjadi, termasuk paradigma dasar mengapa perilaku ini mungkin menjadi penyebabnya (askari et al. et al., 2017). berdasarkan faktor-faktor penyebab krisis dan fondasi stabilitas keuangan islam menghadapi krisis tersebut, tulisan ini berupaya membentuk paradigma system keuangan islam menghadapi krisis keuangan.

Jika berdasarkan penelitian sebelumnya, setidaknya penyebab krisis keuangan akan terpicu Tiga aspek utama tersebut adalah perilaku 
(behaviour), politik (politics) dan ekonomi (ekonomy). Dalam Aspek perilaku, tindakan spekulatif, ekspektasi, perbuatan kriminal semisal penipuan mampu diatasi dengan penguatan kontrol terhadap perilaku tersebut, pemahaman yang mendalam dan penguatan nilai-nilai dan etika ekonomi Islam mengenai perilaku menyimpang semisal perjudian, spekulasi, tindakan melampaui batas dan penipuan menjadi solusi terbaik dalam menghadapinya.

Dalam politik, pemahaman kedua pihak dalam memainkan peran paling penting Pengaturan keuangan dan kondisi control Mempengaruhi sistem keuangan yaitu pemerintah dan bank sentral (Alrifai, 2015, h. 73) Sangat penting. Memahami peran dan tanggung jawab mereka, dan memperkuat regulasi terkait aturan perdagangan Keuangan Islam, dan memaksimalkan peran pembuat aturan (Regulatory agency) agar dapat mempengaruhi perilaku peserta transaksi Pembiayaan pasar juga menjadi masalah yang harus diperhatikan. Dalam Kasus Indonesia, support terhadap lembaga-lembaga yang menguatkan dan mendukung regulator tersebut juga menjadi penting, semisal peranan Komite Nasional Keuangan Syariah (KNKS), Dewan Syariah Nasional Majelis Ulama Indonesia (DSN-MUI).

Pada aspek ekonomi, Penguatan terhadap larangan riba, peningkatan dan dukungan terhadap sektor riil ekonomi serta maksimalisasi peran lembaga keuangan sosial Islam (Islamic Social Finance) juga menjadi salah satu langkah dalam menguatkan sistem keuangan Islam dalam menghadapi setiap krisis yang datang. Oleh karena itu sesuai dengan alasannya Prinsip utama Islam adalah menetapkan solusi untuk menghadapi krisis secara paradigm Seperti yang ditunjukkan di bawah ini: 


\begin{tabular}{|c|c|c|}
\hline $\begin{array}{l}\text { Problem } \\
\text { utama }\end{array}$ & Penyebab & Solusi \\
\hline \multirow[t]{13}{*}{$\begin{array}{l}\text { Financial } \\
\text { crisis }\end{array}$} & \multirow[t]{5}{*}{$\begin{array}{c}\text { perilaku } \\
\text { (behaviour) }\end{array}$} & $\begin{array}{l}\text { Penguatan control pelanggaran } \\
\text { syariah }\end{array}$ \\
\hline & & Larangan spekulatif \\
\hline & & Larangan berjudi \\
\hline & & Larangan dzalim dan menitpu \\
\hline & & Penerapan etika ekonomi \\
\hline & \multirow[t]{4}{*}{ politik (politics) } & $\begin{array}{l}\text { Penguatan regulasi keuangan } \\
\text { islam }\end{array}$ \\
\hline & & $\begin{array}{l}\text { Penguatan dan maksimalisasi } \\
\text { peran KNKS dan DSN-MUI }\end{array}$ \\
\hline & & $\begin{array}{l}\text { Penguatan pembuat kebijakan } \\
\text { keuangan (pemerintah dan bank } \\
\text { sentral) }\end{array}$ \\
\hline & & $\begin{array}{l}\text { Regulasi khusus pada control } \\
\text { perilaku dan buka pada } \\
\text { mekanisme pasar dan keuangan }\end{array}$ \\
\hline & \multirow{4}{*}{$\begin{array}{l}\text { ekonomi } \\
\text { (ekonomy) }\end{array}$} & Penerapan ekonomi bebas riba \\
\hline & & Transfer resiko transaksi \\
\hline & & $\begin{array}{l}\text { Penguatan produksi berdasarkan } \\
\text { etika ekonomi islam }\end{array}$ \\
\hline & & $\begin{array}{l}\text { Penguatan Islamic social finance } \\
\text { sebagai instrumen }\end{array}$ \\
\hline
\end{tabular}

Tabel di atas merupakan contoh pemberian solusi stabilitas keuangan Islam dan pencegahan krisis keuangan. Krisis keuangan yang dipicu oleh penyebab krisis yang disebabkan oleh perilaku abnormal dalam aktivitas keuangan, berdasarkan paradigma stabilitas keuangan Islam dapat diatasi dan dicegah oleh pemerintah dan regulator yang menegakkan peraturan secara ketat dan menerapkan solusi pengendalian perilaku di bawah pengawasan yang cermat.

Di sisi lain, pemicuan krisis politik dapat diatasi dan dicegah dengan memperkuat politik keuangan syariah dari segi aturan (regulasi), lembaga yang berwenang (pemerintah dan bank sentral), dan lembaga strategis yang berperan penting dalam pembangunan Keuangan Islam. Sementara itu, krisis keuangan yang disebabkkan karena mekanisme ekonomi dan akibat kelemahan Ekonomi Konvensional bisa diselesaikan dan ditegahi dengan penerapan mekanisme-mekanisme dasar dalam Ekonomi Islam semisal pelarangan riba, transfer resiko transaksi berdasarkan akad-akad 
beragam dalam Ekonomi Islam, produksi dan konsumsi yang dilandasi etika Ekonomi Islam serta penguatan Sistem Keuangan sosial Islam Zakat, Infaq Shadaqah serta Wakaf sebagai Instrumen perekonomian.

\section{KESIMPULAN DAN KETERBATASAN}

Fenomena krisis berulang yang diprediksi kembali terjadi bisa diatasi dengan Sistem Keuangan Islam, dengan catatan bahwa penguatan terhadap Keuangan Islam tersebut dilaksanakan di segala sisi dalam rangka mengantisipasi krisis. Penelitian-penelitian selanjutnya yang bersifat empiris diharapkan mampu menyoroti indikator-indikator perilaku, politik dan Ekonomi sebagai main causes terjadinya krisis dengan hipotesis bahwa jika pengaturan perilaku, politik dan ekonomi semakin dekat kepada Islam maka krisis keuangan akan mampu dihadapi dengan lebih baik. Bagi para pembuat kebijakan, perlu memperhatikan dan mengontrol tindakan para pelaku transaksi keuangan agar dapat terus bertindak sesuai dengan nilai-nilai Islam dan secara serius memperkuat institusi yang mendorong kerjasama dengan regulator dan membuat kebijakan untuk memperkuat sistem keuangan Islam,

Pada akhirnya, kita harus memberikan perhatian yang serius terhadap kebijakan ekonomi bebas dari transaksi ribawi, dan arah kebijakan ekonomi yang didasarkan pada kaidah etika dan Islam mengenai produksi, konsumsi, dan kebijakan distribusi guna mencapai tujuan stabilitas keuangan dan ekonomi. Selain itu, dalam penerapan sistem keuangan Islam, mashlahah seharusnya bisa dirasakan.

\section{DAFTAR PUSTAKA}

Akhtar, S., \& Jahromi, M. 2017. Impact of the global financial crisis on Islamic and conventional stocks and bonds. Accounting and Finance, 57(3), 623-655. http://doi.org/10.1111/acfi.12136

Akhter, W., Pappas, V., \& Khan, S. U. 2017. A comparison of Islamic and conventional insurance demand: Worldwide evidence during the Global Financial Crisis. Research in International Business and Finance, 42(October 2016), 1401-1412. https://doi.org/10.1016/j.ribaf.2017.07.079

Alexakis, C., Izzeldin, M., Johnes, J., \& Pappas, V. 2019. Performance and productivity in Islamic and conventional banks: Evidence from 
the global financial crisis. Economic Modelling, 79(October 2018), 1-14. https://doi.org/10.1016/j.econmod.2018.09.030

Almoharby, D. 2011. The Current World business Meltdown: Islamic religion as a Regulator. Humanomics, 27(2), 97-108.

Alqahtani, F., \& Mayes, D. G. 2018. Financial stability of Islamic banking and the global financial crisis: Evidence from the Gulf Cooperation Council. Economic Systems, 42(2), 346-360. https://doi.org/10.1016/j.ecosys.2017.09

Alrifai, T. 2015. Islamic Finance and the New Financial System. Singapore: Wiley.

Aryani, S. 2015. Implikasi Krisis Keuangan Global Terhadap Industri Batubara Indonesia Tahun 20018- 2013. JOM FISIP, 2(2), 1-15.

Ascarya. 2017. The real determinants of financial crisis and how to resolve it in Islamic economics perspective. International Journal of Economic Research, 14(13), 501-531.

Askari, H., \& Zahedi, D. 2017. Ideal Islamic Economy: An Introduction. In International Journal of Economics, Management and Accounting (E-book, Vol. 26). https://doi.org/10.1057/978-1- 137-53727-0

Bendassolli, P. F. 2013. Theory Building in Qualitative Research: Reconsidering the Problem of Induction. Forum: Qualitative Social Research Sozialforschung, 14(1).

Calvo, G. A. 1987. Balance of Payments Crises in a Cash-in-Advance Economy. Journal of Money, Credit and Banking, 19(1), 19-32.

Chapra, M. U. 2008, The Global Financial Crisis: Can Islamic Finance Help Minimize the Severity and Frequency of Such a Crisis in the Future?. Paper. Presented at the Forum on the Global Financial Crisis to be held at the Islamic Development Bank.

Derbali, A. 2015. Islamic banking during the financial crisis of 2007. Serbian Journal of Management, 10(1), 89-108. https://doi.org/10.5937/sjm10-6402

Diaz-Alejandro, C. 1985. Good-bye Financial Repression, Hello Financial Crash. Journal of Development Economics, 19, 1-24.

Drazen, A., \& Helpman, E. 1987. Stabilization with Exchange rate management. The Quarterly Journal of Economics, 102(4), 835856.

Feeney, A., \& Heit, E. 2007. Inductive Reasoning: Experimental, Developmental, and Computational Approaches. Cambridge University Press.

Flood, R. P., \& Garber, P. M. 1984. Collapsing Exchange-Rate Regimes: Some linear examples. Journal of International Economics, 17, 113. 
Furqani, H. 2015. The Discipline in The Making: Appraising The Progress of Islamic Economics. Journal of Islamic Monetary Economics and Finance, $\quad 1(1), \quad 1-23$. https://doi.org/https://doi.org/10.21098/jimf.v1i1.481

Hamdi, B., Abdouli, M., Ferhi, A., Aloui, M., \& Hammami, S. 2019. The Stability of Islamic and Conventional Banks in the MENA Region Countries During the 2007-2012 Financial Crisis. Journal of the Knowledge Economy, 10(1), 365-379. https://doi.org/10.1007/s13132-017- 0456-2

Isaic, R., Smirna, T., \& Paun, C. 2019. A critical view on the mainstream theory of economic cycles. Management \& Marketing. Challenges for the Knowledge Society, 14(1), 48-58. https://doi.org/10.2478/mmcks-2019-0004. Bereitgestellt

Kaminsky, G. L., \& Reinhart, C. M. 1999. The Twin Crises: The Causes of Banking and Balance-OfPayments Problems. The American Economic Review, 89(3), 473-500.

Ketoviki, M., \& Mantere, S. 2010. Two Strategies for Inductive reasoning in Organizational research. The Academy of Management Review, 35(2), 315-333.

Krugman, P. 1979. A Model of Balance-of-Payments Crises. Journal of Money, Credit and Banking, 11(2), 311-325.

Lietaer, B. \& and Dunne, J. 2013, How New Currencies Turn Scarcity into Prosperity: Rethinking Money. San Francisco: Berrett-Koehler Publishers, Inc.

Maghrebi, N., Mirakhor, A., \& lqbal, Z. 2016. Intermediate Islamic Finance. (E-book). Singapore: Wiley.

Minsky, Hyman P. 1982. The Financial Instability Hypothesis: Capitalist Production and The Behavior of The Economy. In Financial Crises: Theory, History and Policy, edited by C. Kindleberger and J.P. Laffargue. Newyork: Cambridge University Press

Minsky, Hyman P. 1989. The Financial Instability Hypothesis: A Clarification (1989). Hyman P. Minsky Archive. Paper 145. http://digitalcommons.bard.edu/hm_archive/145

Minsky, Hyman P. 1992. The Financial Instability Hypothesis, Working Paper, No. 74, Levy Economics Institute of Bard College, Annandale-on-Hudson, NY

Mirakhor, A \& Krichene, N. 2009, Recent Crisis: Lessons for Islamic Fiance. Journal of Islamic Economics, Banking and Finance, Vol. 5, No. 1, pp.9-57

Obstfeld, M., \& Rogoff, K. 1986. Ruling Out Divergent Speculative bubbles. Journal of Monetary Economics, 17, 349-362.

Othman, R., Aris, N. A., Azli, R. M., \& Arshad, R. 2012. Islamic banking: The firewall against the global financial crisis. Journal of Applied 
Business

Research,

28(1),

$9-14$.

https://doi.org/10.19030/jabr.v28i1.6679

Rothbard, M. N. 2009, Man, Economy, and State with Power and Market. Auburn, Alabama: Ludwig von Mises Institute.

Siddiqi, Mohammad N. 2009, Current Financial Crisis and Islamic Economics. In Islamic Economic Research Center. Issues in the International Financial Crisis from an Islamic Perspective. Jeddah: Scientific Publishing Center King Abdulaziz University.

Trabelsi, M. A. 2011. The impact of the financial crisis on the global economy: can the Islamic financial system help? Journal of Risk Finance, 12(1), https://doi.org/10.1108/15265941111100049

15-25.

Wijnbergen, S. Van. 1991. Fiscal Deficits, Exchange Rates Crises and Inflation. Review of Economic Studies, 58(1), 81-92.

Zelmanovitz, L. 2011. The Austrian Business Cycle Theory and the recent financial crisis. Criterio Libre, 9(15), 23-58. 